\title{
Effects of Dietary Addition of Bentonite and Probiotics on Meat Characteristics and Health of Hanwoo (Bos taurus coreanae) Steers fed Rice Straw As a Sole Roughage Source (a Field Study)
}

\author{
Wan-Sup Kwak ${ }^{1}$, Sang-Moo Lee ${ }^{2}$ and Young-II Kim ${ }^{1}$ \\ ${ }^{1}$ Animal Science, School of Life Resource and Environmental Sciences College of Natural Sciences, \\ Konkuk University, Danwol-dong 322, Chung-Ju, Chung-Buk, 380-701, Republic of Korea, \\ ${ }^{2}$ Department of Animal Science, Kyungpook National University, Sangju, Kyungbuk, 742-711, \\ Republic of Korea
}

\section{ABSTRACT}

A study was conducted to determine the dietary effects of Na-bentonite $(\mathrm{NaB})$ and probiotics on meat characteristics and health of Hanwoo steers fed rice straw as a sole roughage source. A total of 24 growing Hanwoo steers (avg BW $232 \mathrm{~kg}$ ) were assigned to two treatments which included a control diet (concentrate mix and rice straw) and a treatment diet (control diet $+0.5-1.0 \% \mathrm{NaB}+0.5-1.0 \%$ probiotics. The diets were fed for 22 months up to the time the animals were slaughtered. Dietary treatment increased $(\mathrm{p}<0.05)$ concentrations of trace minerals such as $\mathrm{Zn}, \mathrm{Cu}$, and $\mathrm{Fe}$ in the longissimus muscle compared to the control. The treatment diet did not affect cold carcass weight, yield traits such as backfat thickness, longissimus muscle area, yield index, yield grade and quality traits such as marbling score, meat color, fat color, texture, maturity and quality grade. Blood profiles of growing steers were within the normal ranges for healthy cattle. In conclusion, feeding a combination of clay mineral and probiotics to Hanwoo steers fed rice straw as a sole roughage source could have a desirable effect on improving trace mineral retention in longissimus muscle without any deleterious effects on carcass traits of steers.

(Key words : Bentonite, Probiotics, Trace mineral, Meat quality, Hanwoo)

\section{I . INTRODUCTION}

Na-bentonite $(\mathrm{NaB})$ is an expanded lattice clay of the montmorillonite group of minerals (Bates and Jackson, 1980) with a high ion exchange capacity that binds a wide range of cations (Fenn and Leng, 1989). Incorporated into diets, it has improved wool growth of sheep (Fenn and Leng, 1989; Cobon et al., 1992), decreased ruminal ammonia concentrations, and improved feed and bacterial protein flow to the small intestine of ruminants (Ivan et al., 1992). Because acid buffering capacity has been correlated with total cations and total ash (Jasaitis et al., 1987), mineral buffers such as $\mathrm{NaB}$ might be effective in alleviating acid stress in ruminants under intensive feeding and management programs. The swelling capacity of $\mathrm{NaB}$ might provide a

Corresponding author: Prof. Wan Sup Kwak (Ph. D.), School of Life Resource and Environmental Sciences, College of Natural Sciences, Konkuk University, Chung-Ju, Chung-Buk, 380-701, Republic of Korea. Tel: 82-43-840-3521, Fax: 82-43-851-8675, E-mail: wsk@kku.ac.kr 
desirable habitat niche for probiotic microbes in the ruminant digestive tract.

It is well known that probiotic microbes improve gut microbial balance, feed intake, weight gain and feed efficiency in ruminants (Yoon and Stern, 1995; Krehbiel et al., 2003). Kim et al. (2007) reported that feeding probiotic cultures improved growth, meat quantity and meat quality of Hanwoo steers. However, there is no research conducted on feeding effects of $\mathrm{NaB}$ and probiotics together on cattle. It is, therefore, postulated that the addition of probiotics with $\mathrm{NaB}$ might show a desirable effect on meat quality and quantity.

Based on previous reports of the beneficial effects of bentonite and probiotic cultures incorporated into diets of ruminants, a study was conducted to determine the effects of these dietary additives on meat quality and quantity by Hanwoo steers.

\section{П. MATERIALS AND METHODS}

\section{Animals and treatments}

All animal care protocols were approved by the Konkuk University Institutional Animal Care and Use Committee. Twenty four-Hanwoo (Bos taurus coreanae) steers at 9 mon of age (average BW $232 \mathrm{~kg}$ ) were allotted in groups of 4 steers to each of 6 pens. Four of the pens were located at Farm 1, and 2 at Farm 2 in Boeun County, Chungbuk Province, Korea. Steers were fed one of two rations. Each ration was fed to steers in two pens located at Farm 1 and one pen at Farm 2. The steers were fed a control diet (concentrate mix and rice straw), and a treatment diet (the control diet $+0.5-1.0 \% \mathrm{NaB}+$ 0.5-1.0\% probiotics). Periods for growing, fattening and finishing were 6,8 , and 8 mon, respectively. Diets were fed for 22 mon until the animals were slaughtered.

Feeds and feed additives were supplied daily to the steers in a manner shown in Table 1 . The concentrate mix (Table 2) was fed in a restricted manner to achieve $0.8 \mathrm{~kg}$ levels of average daily gain (ADG) during the growing period, and over $0.9 \mathrm{~kg}$ ADG during the fattening period. Animals had free access to rice straw at all times. The $\mathrm{NaB}$ and probiotics were top-dressed at each feeding time. Feed was supplied twice a day at 07:00 $\mathrm{h}$ and 18:00 h. During the finishing period, the concentrate mix was fed ad libitum and rice straw was restricted at a level of approximately $10 \%$ of concentrate mix.

Animals were observed for health status, and body weight was measured on a monthly basis throughout the study. Samples of concentrate mix and rice straw were collected every 2 wk for proximate analysis.

The chemical composition of the commercial concentrate mix and rice straw fed to the steers is presented in Table 2. The bentonite product (Bionit, Korea Sud Chemical, Korea) used in the study was an extra-purified powder for animal use, and was composed of 75 85\% Montmorillonite, $58 \% \mathrm{SiO}_{2}, 20 \% \mathrm{Al}_{2} \mathrm{O}_{3}, 6 \% \mathrm{Fe}_{2} \mathrm{O}_{3}$, 3.5\% $\mathrm{MgO}, 2.5 \% \mathrm{CaO}, 2 \% \mathrm{Na}_{2} \mathrm{O}$, and $1 \% \mathrm{~K}_{2} \mathrm{O}$. Based on individual minerals, it contained $1.41 \%$ Ca, $0.04 \%$ P, $0.10 \% \mathrm{Mg}, 1.78 \% \mathrm{~K}, 0.66 \% \mathrm{Na}$, 1,631 ppm Fe, 7.9 ppm Zn, 5.0 ppm Cu, and $212 \mathrm{ppm} \mathrm{Mn}$. The $\mathrm{pH}$ was about 10. The swelling volume was $9 \mathrm{~mL} / \mathrm{g}$, and the cation exchange capacity was $80 \mathrm{meq} / 100 \mathrm{~g}$. The specific surface area was $400-600 \mathrm{~m}^{2} / \mathrm{g}$. The probiotics used in the study was a mixture of Bacillus subtilis and Saccharomyces cerevisiae at a viable 
Table 1. Diets for growing, fattening and finishing periods for Hanwoo steers ${ }^{\perp}$

\begin{tabular}{|c|c|c|c|c|}
\hline Item & & Control & & Treatment \\
\hline \multicolumn{5}{|l|}{ Growing period } \\
\hline \multicolumn{2}{|l|}{ Concentrate mix, \% live wt } & 1.44 & & 1.44 \\
\hline \multicolumn{2}{|l|}{ Rice straw } & $\mathrm{FA}^{3)}$ & & FA \\
\hline \multicolumn{2}{|l|}{ Na-Bentonite ${ }^{2)}$, \% conc. mix } & 0 & & 1.0 \\
\hline \multicolumn{2}{|l|}{ Probiotics $^{2)}, \%$ conc. mix } & 0 & & 1.0 \\
\hline \multicolumn{5}{|l|}{ Fattening period } \\
\hline \multicolumn{2}{|l|}{ Concentrate mix, \% live wt } & 1.50 & & 1.50 \\
\hline \multicolumn{2}{|l|}{ Rice straw } & FA & & FA \\
\hline \multicolumn{2}{|l|}{ Na-Bentonite ${ }^{2)}$, \% conc. mix } & 0 & & 0.5 \\
\hline \multicolumn{2}{|l|}{ Probiotics $^{2)}, \%$ conc. mix } & 0 & & 0.5 \\
\hline \multicolumn{5}{|l|}{ Finishing period } \\
\hline \multicolumn{2}{|l|}{ Concentrate mix } & FA & & FA \\
\hline \multicolumn{2}{|l|}{ Rice straw, \% conc. mix } & 10 & & 10 \\
\hline \multicolumn{2}{|l|}{ Na-Bentonite ${ }^{2)}, \%$ conc. mix } & 0 & & 0.5 \\
\hline \multicolumn{5}{|c|}{$\begin{array}{l}\text { 1) Dry matter basis. } \\
\text { 2) Each of Na-bentonite and probiotics was top-dressed on concentrate (conc.) mix at each feeding time. } \\
{ }^{3)} \text { FA means 'free access' to rice straw or concentrate mix all the time. }\end{array}$} \\
\hline \multicolumn{5}{|c|}{ Table 2. Chemical composition of concentrate mix and rice straw ${ }^{1,, 2), 3)}$} \\
\hline \multirow{2}{*}{ Item } & \multicolumn{3}{|c|}{ Concentrate mix } & \multirow{2}{*}{ Rice straw } \\
\hline & Growing & Fattening & Finishing & \\
\hline & \multicolumn{4}{|c|}{ 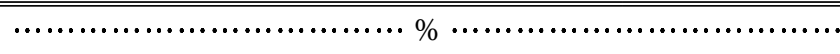 } \\
\hline Dry matter & 88.0 & 88.0 & 85.8 & 86.8 \\
\hline Organic matter & 92.3 & 91.5 & 93.2 & 89.8 \\
\hline Ether extract & 3.6 & 3.1 & 3.0 & 0.7 \\
\hline Crude protein & 15.7 & 14.1 & 14.0 & 3.7 \\
\hline Neutral detergent fiber & 29.8 & 27.2 & 25.8 & 75.7 \\
\hline Acid detergent fiber & 13.9 & 19.6 & 15.3 & 46.9 \\
\hline Crude ash & 7.7 & 8.5 & 6.8 & 10.2 \\
\hline Minimum target TDN & 80.7 & 80.7 & 81.8 & - \\
\hline
\end{tabular}

1) Dry matter basis.

${ }^{2)}$ Means of 3 observations.

${ }^{3)}$ Ingredient composition (as-fed basis) of concentrate mix was as follows: corn grain 22.5\%, wheat $18.0 \%$, molasses $5.5 \%$, wheat bran $21.0 \%$, corn gluten meal $4.5 \%$, rapeseed meal $7.0 \%$, coconut meal $7.0 \%$, palm meal $11.0 \%$, $\mathrm{NaCl} 0.6 \%$, limestone $2.0 \%$, vitamin premix $0.1 \%$, mineral premix $0.1 \%$ and other additives $0.7 \%$ for the growing period; corn grain $22.0 \%$, wheat $18.0 \%$, molasses $5.5 \%$, tapioca $8.0 \%$, wheat flour $3.0 \%$, wheat bran $12.7 \%$, rapeseed meal $4.4 \%$, coconut meal $7.0 \%$, palm meal $11.0 \%$, mixed hays $5.0 \%$, $\mathrm{NaCl}$ $0.6 \%$, limestone $2.0 \%$, vitamin premix $0.1 \%$, mineral premix $0.1 \%$ and other additives $0.6 \%$ for the fattening period; corn grain $29.7 \%$, wheat $18.0 \%$, molasses $6.0 \%$, tapioca $8.0 \%$, wheat bran $4.0 \%$, corn gluten meal $10.3 \%$, distiller's rice $1.0 \%$, coconut meal $5.05 \%$, palm meal $11.0 \%$, mixed hays $4.0 \%$, $\mathrm{NaCl} 0.6 \%$, limestone $1.5 \%$, vitamin premix $0.1 \%$, mineral premix $0.1 \%$ and other additives $0.6 \%$ for the finishing period. 
cell concentration in excess of $10^{6} \mathrm{cfu} / \mathrm{g}$ for each culture. The cultures were grown on rice bran and the culture mixture had $85 \% \mathrm{DM}$, $16.0 \%$ CP, $14.0 \%$ ether extract (EE), 6.3\% crude fiber (CF) and $10.3 \%$ crude ash. Based on the individual minerals, the probiotics contained $0.19 \% \quad \mathrm{Ca}, \quad 1.41 \% \quad \mathrm{P}, \quad 0.25 \% \quad \mathrm{Mg}, \quad 1.79 \% \quad \mathrm{~K}$, 0.04\% Na, 231 ppm Fe, 40 ppm Zn, 6.9 ppm $\mathrm{Cu}$, and $184 \mathrm{ppm} \mathrm{Mn}$.

The control diet (concentrate mix + rice straw) was lack in trace mineral contents as shown in Table 3. Dietary Zn levels in growing, fattening and finishing periods, respectively were lower than NRC (2000) requirement of beef cattle. Dietary $\mathrm{Cu}$ levels according to the periods were much lower than the requirement (NRC, 2000). When the control diet was added with $\mathrm{NaB}$ and probiotics, the levels of $\mathrm{Zn}$ and $\mathrm{Cu}$ (48 and 12 ppm, respectively) were higher than the NRC requirement (NRC, 2000).

\section{Sampling and chemical analysis}

Feed samples taken from troughs prior to feeding were dried and ground to pass through a $1 \mathrm{~mm}$ screen using a Sample Mill (Cemotec, Tecator, Sweden). The content of dry matter was determined by drying samples at $105^{\circ} \mathrm{C}$ for $24 \mathrm{~h}$ to constant weight. The contents of crude protein, EE, acid detergent fiber (ADF), and ash were determined by the AOAC methods (2000). The content of ash free neutral detergent fiber (NDF) was determined according to the method of Van Soest et al. (1991). Organic matter (\%) was determined as 100 minus ash \%.

Steers were withdrawn from the experimental diets $24 \mathrm{~h}$ before slaughter. Following a 24-h carcass chill, yield and quality grades were assigned to each carcass using Korean carcass grading standards specified in the attached list No. 4 of Korean Livestock Enforcement Regulation (KLER, 2007). The 12th to 13th rib longissimus muscle was removed, retained from each steer and frozen until later analysis.

For mineral analysis of the rib muscle, samples were analyzed for $\mathrm{Ca}, \mathrm{P}, \mathrm{Ma}, \mathrm{K}, \mathrm{Na}$, $\mathrm{Mn}, \mathrm{Fe}, \mathrm{Zn}$ and $\mathrm{Cu}$ by inductively coupled argon plasma emission spectroscopy (ICP-OES 5300DV, Perkin Elmer, USA) as described by Braselton et al. (1997).

For animal health diagnosis, blood samples were taken from jugular vein of steers during the growing period and an equal portion was divided into bottles with or without anti-coagulant EDTA. Serum profiles were analyzed using an Automatic Biochemical Analyzer (Hitachi 7170A, Hitachi Ltd., Tokyo, Japan) based on photometer and ion selective electrode methods, and whole blood profiles were analyzed with an Automatic Blood

Table 3. $\mathrm{Zn}$ and $\mathrm{Cu}$ levels in the control diet according to feeding periods ${ }^{1)}$

\begin{tabular}{|c|c|c|c|c|}
\hline & \multicolumn{3}{|c|}{ Period } & \multirow{2}{*}{$\begin{array}{c}\text { Requirement } \\
\text { of beef cattle }{ }^{2)}\end{array}$} \\
\hline & Growing & Fattening & Finishing & \\
\hline & \multicolumn{4}{|c|}{ 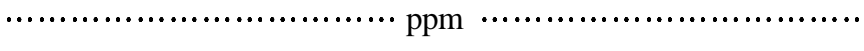 } \\
\hline $\mathrm{Zn}$ & 28 & 19 & 21 & 30 \\
\hline $\mathrm{Cu}$ & 6 & 4 & 5 & 10 \\
\hline
\end{tabular}

1) Dry matter basis.

${ }^{2)}$ Cited from NRC (2000). 
Analyzer (Coulter STKS, Beckman Coulter Co., Miami, FL, USA) based on impedance and VCS (volume, conductivity, light scattering) methods.

\section{Statistical analysis}

Data were analyzed using farms as a block in a randomized complete block design by the General Linear Model (SAS Institute, Inc., 1990). Comparison of means between control and $\mathrm{NaB}$ treatment was made using studentized-t test (SAS Institute, Inc., 1990). Significant differences were detected at $\mathrm{p}<0.05$.

\section{RESULTS AND DISCUSSION}

\section{Meat mineral profile}

The effect of the dietary treatment on the meat mineral profiles of steers is presented in Table 4. Feeding a diet (treatment) added with $\mathrm{NaB}$ and probiotics affected $(\mathrm{p}<0.05)$ the mineral concentrations in the longissimus muscle. Compared with the control, the treatment increased concentrations of $\mathrm{Zn}, \mathrm{Cu}, \mathrm{Fe}, \mathrm{P}, \mathrm{Mg}$ and $\mathrm{Na}$, but concentrations of $\mathrm{Mn}, \mathrm{Ca}$ and $\mathrm{K}$ were not affected. The longissimus muscle of steers assigned to the treatment had higher levels of $\mathrm{Zn}(49.0 \%), \quad \mathrm{Cu}(100 \%), \quad \mathrm{Fe}$ (34.5\%), P (49.3\%), $\mathrm{Mg}$ (46.1\%), and $\mathrm{Na}$ (43.9\%) than the control group. Individual herd data showed little variation associated with the increasing rates of the specific minerals (data not presented). The mineral concentrations ranged between the values reported by Westing et al. (1985) and Williams et al. (1983). However, Cu levels in the present study were rather low compared with those reported by Salles et al. (2008). This difference was attributed to the different analytical method. In a short term study with lambs Walz et al. (1998) reported a diet with $0.75 \%$ bentonite did not affect concentrations of $\mathrm{Zn}, \mathrm{Cu}, \mathrm{Mn}, \mathrm{Fe}, \mathrm{Ca}$, $\mathrm{Mg}$, and $\mathrm{K}$ in bone, liver and kidney.

The control diet in this study contained more $\mathrm{Fe}, \mathrm{Mn}, \mathrm{K}$ and $\mathrm{Na}$ and less $\mathrm{Zn}, \mathrm{Cu}$, and $\mathrm{Mg}$ (data not presented) than the dietary requirement specified in KFSEC (2007) and NRC (2000). Dietary supplementation of these deficient minerals

Table 4. Mineral profiles (ppm) in the longissimus muscle of Hanwoo steers fed different $\operatorname{diets}^{1)}$

\begin{tabular}{lccc}
\hline Item & Control & Treatment & SE \\
\hline \hline Trace minerals & & & \\
Zn & 39.4 & 58.7 & $4.1^{\mathrm{a}}$ \\
$\mathrm{Cu}$ & 2.2 & 4.4 & $0.9^{\mathrm{a}}$ \\
$\mathrm{Fe}$ & 26.7 & 35.9 & $2.5^{\mathrm{a}}$ \\
$\mathrm{Mn}$ & 0.12 & 0.11 & 0.03 \\
\hline Major minerals & & & \\
$\mathrm{Ca}$ & 146.2 & 145.7 & 23.1 \\
$\mathrm{P}$ & 2,225 & 3,323 & $238^{\mathrm{a}}$ \\
$\mathrm{Mg}$ & 232 & 339 & $25^{\mathrm{a}}$ \\
$\mathrm{K}$ & 4,250 & 6,061 & 438 \\
$\mathrm{Na}$ & 618 & 889 & $63^{\mathrm{a}}$ \\
\hline
\end{tabular}

${ }^{a}$ Control diet differs from treatment $(\mathrm{p}<0.05)$.

${ }^{1)}$ Means of 12 observations. 
especially for the treatment resulted in a higher $\mathrm{Zn}, \mathrm{Cu}$, and $\mathrm{Mg}$ retention in the longissimus muscle. Zinc and $\mathrm{Cu}$ are essential trace minerals and perform important biochemical functions. These minerals are deficient in typical human diet; however, $\mathrm{Cu}$ deficiency is more common and important in the elderly diet (Subar et al., 1998; Ma and Betts, 2000). Cao et al. (2000) reported that $\mathrm{Zn}$ supplementation of ruminant diets that were deficient in $\mathrm{Zn}$ resulted in increased $\mathrm{Zn}$ content of the ruminant muscle.

The biological reasons for the improved effects of dietary $\mathrm{NaB}$ on mineral metabolism are not apparent. The improved bioavailability of mineral might be due to the high swelling capacity of $\mathrm{NaB}$ resulting in a slowing in the rate of digesta passage through the gastrointestinal tract or might be related to the high cation exchange capacity of $\mathrm{NaB}$.

The use of microorganisms in animal diets has been shown to improve mineral balance. Yoon and Stern (1995) reported that yeast culture supplementation improved retention of minerals $(\mathrm{Cu}, \mathrm{Fe}$ and $\mathrm{K})$ in growing ruminants and Cole et al. (1992) reported that lambs fed yeast culture tended to have a better balance of $\mathrm{Zn}$ and Fe. The present study showed there might be a desirable trace mineral retention when a diet was supplemented with both $\mathrm{NaB}$ and probiotics. This phenomenon may be possibly due to a better microbial habitat attributed to the swelled $\mathrm{NaB}$ in the digestive tract and also due to an improved mineral uptake by the microbes.

\section{Meat characteristics}

The effects of the dietary treatments on meat characteristics are presented in Table 5. The cold carcass weights were $20 \mathrm{~kg}$ higher for the treatment than for the control, but the difference was not significant. Also, the dietary treatment did not affect carcass yield traits including backfat thickness, longissimus muscle area, yield index and yield grade and quality traits including marbling score, meat color, fat color, texture, maturity and quality grade. For the meat quality grades the number of carcasses graded as $1^{++}, 1^{+}, 1,2$, and 3 grades were $2,3,4,2$, and 1 for the control group and $1,2,8,1$, and 0 for the treatment group.

Overall the dietary treatment had a beneficial effect on the carcass quality grades. In another study (Walz et al., 1998), feeding 0.75\% $\mathrm{NaB}$ did not affect carcass weight, longissimus muscle area, backfat thickness, quality grade nor yield grade of lambs. The differences in response to $\mathrm{NaB}$ could be due to different feeding periods and contents. When beef steers were supplemented with Zn, carcass weights were increased (Spears and Kegley, 2002). A previous study by Kim et al. (2007) reported no effect on meat characteristics when $1 \%$ of probiotic culture was fed to steers.

\section{Blood profiles}

The blood profiles of the Hanwoo steers are presented in Table 6. For blood nutrients, the dietary treatment did not show any differences in blood concentrations of triglyceride, cholesterol, high density lipoprotein, low density lipoprotein, glucose and protein. These results indicate that fat, energy and protein metabolisms within the animal body were not affected by the treatment.

The blood electrolytes $\mathrm{Ca}, \mathrm{P}$ and $\mathrm{K}$ were not affected by the treatment, but blood $\mathrm{Na}$ and $\mathrm{Cl}$ levels were lower $(\mathrm{p}<0.05)$ compared to steers 
Table 5. Meat characteristics of Hanwoo steers fed different diets ${ }^{\perp)}$

\begin{tabular}{lccc}
\hline Item & Control & Treatment & SE \\
\hline \hline Cold carcass weight, kg & 403 & 423 & 20 \\
\hline Yield traits & & & \\
$\quad$ Backfat thickness, mm & 16.8 & 14.4 & 1.6 \\
Longissimus muscle area, cm ${ }^{2}$ & 82.3 & 84.9 & 3.1 \\
Yield index & 61.9 & 63.3 & 1.2 \\
Yield grade $^{2)}$ & 2.34 & 2.38 & 0.16 \\
\hline Quality traits & & & \\
Marbling score $^{3)}$ & 4.88 & 4.50 & 0.65 \\
Meat color $^{4)}$ & 4.50 & 4.31 & 0.16 \\
Fat color $^{5)}$ & 2.84 & 2.94 & 0.07 \\
Texture $^{6)}$ & 1.31 & 1.19 & 0.16 \\
Maturity $^{7)}$ & 2.19 & 2.06 & 0.14 \\
Quality grade $^{8)}$ & 2.75 & 2.88 & 0.37 \\
\hline
\end{tabular}

1) Means of 12 observations.

2) Scored : grade $\mathrm{A}=1$ (lean), $\mathrm{B}=2, \mathrm{C}=3$ (fat).

3) Scored : grade 1 = poor, grade $9=$ excellent.

4) Scored : grade 1 = scarlet, grade $7=$ dark red.

5) Scored : grade 1 = white, grade 7 = yellow.

6) Scored : grade 1 = good, grade 3 = bad.

7) Scored : grade 1 = fully mature, grade $9=$ least mature.

${ }^{8)}$ Scored : grade $1^{++}=1$ (best), $1^{+}=2,1=3,2=4,3=5$ (poorest).

on the control diet. In a similar study (Ha et al., 1985), feeding $2 \% \mathrm{NaB}$ to lambs did not affect concentrations of blood $\mathrm{Ca}, \mathrm{P}$, and $\mathrm{K}$, but $\mathrm{Na}$ content decreased. Also, in another study of Pulsipher et al. (1994), feeding $\mathrm{NaB}$ decreased blood $\mathrm{Na}$ and $\mathrm{Cl}$ levels. The exact reason for decreased blood $\mathrm{Na}$ and $\mathrm{Cl}$ leves was not explained. But they also could be associated with non-dietary factors such as hormone levels of the animals on the different diets (Church and Pond, 1982).

Blood enzyme analyses showed little effect of the dietary treatments on liver and kidney function because steers on the treatment had similar concentrations of blood aspartate aminotransferase and lactate dehydrogenase. Blood cell counts were not affected by the treatment. Generally, values for all blood constituents were within the normal range for healthy cattle (Church and Pond, 1982; Wallach, 1974). In a similar study, Cho et al. (2001) reported that feeding clay minerals to growing Hanwoo steers did not affect their red and white blood cell counts. Pulsipher et al. (1994) reported that feeding $42 \mathrm{~g} / \mathrm{d} \mathrm{NaB}$ to lambs did not affect their blood nutrients, electrolytes, and enzymes, but there was a decrease in serum $\mathrm{Na}$ and $\mathrm{Cl}$ concentrations. None of the steers showed 
Table 6. Blood profiles of Hanwoo steers fed different diets ${ }^{\perp}$

\begin{tabular}{|c|c|c|c|}
\hline Item & Control & Treatment & SE \\
\hline Triglyceride, mg/dL & 29.8 & 24.6 & 2.9 \\
\hline Cholesterol, mg/dL & 154.7 & 143.6 & 11.4 \\
\hline High density lipoprotein, mg/dL & 121.3 & 113.8 & 8.5 \\
\hline Low density lipoprotein, mg/dL & 29.9 & 27.6 & 4.1 \\
\hline Glucose, mg/dL & 69.8 & 71.0 & 3.0 \\
\hline Total protein, g/dL & 6.58 & 6.63 & 0.17 \\
\hline \multicolumn{4}{|l|}{ Electrolytes } \\
\hline Calcium $\left(\mathrm{Ca}^{+}\right), \mathrm{mg} / \mathrm{dL}$ & 9.43 & 9.58 & 0.22 \\
\hline Inorganic phosphorus $\left(\mathrm{P}^{-}\right), \mathrm{mg} / \mathrm{dL}$ & 8.16 & 8.03 & 0.35 \\
\hline Potassium $\left(\mathrm{K}^{+}\right), \mathrm{mM} / \mathrm{L}$ & 5.40 & 5.09 & 0.14 \\
\hline Sodium $\left(\mathrm{Na}^{+}\right), \mathrm{mM} / \mathrm{L}$ & 145.8 & 144.1 & $0.8 \mathrm{a}$ \\
\hline Chlorine $\left(\mathrm{Cl}^{-}\right), \mathrm{mM} / \mathrm{L}$ & 103.7 & 101.8 & $0.8 \mathrm{a}$ \\
\hline Albumin, g/dL & 3.01 & 2.93 & 0.07 \\
\hline Globulin, g/dL & 3.58 & 3.70 & 0.16 \\
\hline Albumin/globulin & 0.87 & 0.80 & 0.05 \\
\hline Uric acid, mg/dL & 1.22 & 1.13 & 0.06 \\
\hline Total bilirubin, mg/dL & 0.10 & 0.11 & 0.01 \\
\hline Alkaline phosphatase, IU/L & 539 & 486 & 64 \\
\hline Alanine aminotransferase, IU/L & 25.3 & 23.9 & 1.8 \\
\hline Aspartate aminotransferase, IU/L & 85.1 & 91.5 & 4.9 \\
\hline r-glutamyltransferase, IU/L & 21.9 & 21.7 & 2.2 \\
\hline Lactate dehydrogenase, IU/L & 1285 & 1349 & 49 \\
\hline Amylase, IU/L & 27.6 & 27.8 & 2.2 \\
\hline Urea-N, mg/dL & 10.7 & 10.5 & 0.9 \\
\hline Creatinine, mg/dL & 1.26 & 1.27 & 0.06 \\
\hline White blood cell counts, $10^{3} / \mu \mathrm{L}$ & 25.0 & 32.4 & 6.5 \\
\hline Red blood cell counts, $10^{6} / \mu \mathrm{L}$ & 7.27 & 6.91 & 0.31 \\
\hline Platelet counts, $10^{3} / \mu \mathrm{L}$ & 241 & 299 & 55 \\
\hline
\end{tabular}

${ }^{a}$ Control diet differs from treatment $(\mathrm{p}<0.05)$.

${ }^{1)}$ Means of 12 observations.

abnormal health problems throughout the in the longissimus muscle of steers. In experimental periods. conclusion, the combined use of clay mineral In summary, the addition of $\mathrm{NaB}$ and and probiotics in the animal diet improved probiotics to the diet of Hanwoo steers increased mineral retention in muscle without any concentrations of trace minerals $(\mathrm{Zn}, \mathrm{Cu}$, and $\mathrm{Fe})$ deleterious effects on carcass traits of Hanwoo 
steers.

\section{ACKNOLEDGEMENTS}

This study was conducted by means of a grant from the Agenda Research Program (PJ006852072012) of the Rural Development Administration, Korea. Special thanks go to the Boeun County Agriculture Technology in ChungBuk province for their active support.

\section{REFERENCES}

AOAC. 2000. Official methods of analysis. 17th ed, Association of Official Analytical Chemists, Washington, D. C.

Bates, R.L. and Jackson, J.A. 1980. Glossary of Geology. American Geological Institute, Alexandria, VA.

Braselton, W.E., Stuart, K.J., Mullaney, T.P. and Herdt, T.H. 1997. Biopsy mineral analysis by inductively coupled plasma-atomic emission spectroscopy with ultrasonic nebulization. Journal of Veterinary Diagnosis and Investigation 9:395400 .

Cao, J., Henry, P.R., Guo, R., Holwerda, R.A., Toth, J.P., Littell, R.C., Miles, R.D. and Ammerman, C.B. 2000. Chemical characteristics and relative bioavailability of supplemental organic zinc sources for poultry and ruminants. Journal of Animal Science 78:2039-2054.

Cho, W.M., Paek, B.H., Kang, S.W., Kim, J.S. and Kim, Y.K. 2001. Effects of dietary supplements of clay minerals on the growth performance and immunity in growing Hanwoo steers. Korean Journal of Animal Science and Technology 43: 203-210.

Church, D.C. and Pond, W.G. 1982. Nutrient metabolism. In: Basic Animal Nutrition and Feeding. John Wiley and Sons, NY.

Cobon, D.H., Stephenson, R.G.A. and Hopkins, P.S. 1992. The effect of oral administration of methionine, bentonite, methionine/bentonite and methionine/oil homogenates on wool production of grazing and penned sheep in a semi-arid tropical environment. Journal of Animal Science 48:641648.

Cole, N.A., Purdy, C.W. and Hutcheson, D.P. 1992. Influence of yeast culture on feeder calves and lambs. Journal of Animal Science 70:1682- 1690.

Fenn, P.D. and Leng, R.A. 1989. Wool growth and sulfur amino acid entry rate in sheep fed roughage based diets supplemented with bentonite and sulfur amino acids. Australasian Journal of Agricultural Resources 40:889-896.

Ha, J.K., Emerick, R.J. and Embry, L.B. 1985. Effect of bentonite and limestone on the growth rate and plasma mineral concentrations of fattening lambs. Korean Journal of Animal Science 27:24-28.

Ivan, M., Dayrell, M.D., Mahadevan, S. and Hidiroglou, M. 1992. Effects of bentonite on wool growth and nitrogen metabolism in fauna-free and faunated sheep. Journal of Animal Science 70: 3194-3202.

Jasaitis, D.K., Wohlt, J.E. and Evans, J.L. 1987. Influence of feed ion content on buffering capacity of ruminant feedstuffs in vitro. Journal of Dairy Science 70:1391-1403.

Kim, S.H., Hyun, S.H., Lee, S.M., Hwang, J.H., Jeon, B.T., Moon, S.H. and Sung, S.H. 2007. Effects of supplementation period and levels of fermented mineral feed (Power-Mix) on the growth and carcass characteristics of Hanwoo steer. Korean Journal of Food Science and Animal Resource 27: 450-456.

Korean Feeding Standard Establishment Council. 2007. Korean Feeding Standard for Korean Cattle (Hanwoo). National Livestock Research Institute, RDA, Ministry of Agriculture and Forestry, Korea. Korean Livestock Enforcement Regulation. 2007. Korean carcass grading standards. An attached list No. 4, Revised 2007. 6.19, KDAF, Korea.

Krehbiel, C.R., Rust, S.R., Zhang, G. and Gilliland, S.E. 2003. Bacterial direct-fed microbials in ruminant diets: Performance response and mode of action. Journal of Animal Science 81:E120-E132.

Ma, J. and Betts, N.M. 2000. Zinc and copper intakes and their major food sources for older adults in the 1994-96 continuing survey of food intakes by individuals (CSFII). The Journal of Nutrition 130: 2838-2843. 
NRC. 2000. Nutrient requirements of beef cattle. Update 2000, National Academy Press, Washington, D.C.

Pulsipher, G.D., Galyean, M.L., Hallford, D.M., Smith, G.S. and Kiehl, D.E. 1994. Effects of graded levels of bentonite on serum clinical profiles, metabolic hormones, and serum swain- sonine concentrations in lambs fed locoweed (Oxytropis sericea). Journal of Animal Science 72:1561-1569.

Salles, M.S.V., Zanetti, M.A. and Salles. F.A. 2008. Effect of monensin on mineral balance in growing ruminants reared under different environ- mental temperatures. Animal Feed Science and Technology 141:233-245.

SAS Institute, Inc. 1990. SAS User's Guide. Version 6.08. Fourth Ed., SAS Inst., Inc., Cary, NC, USA. Spears, J.W. and Kegley, E.B. 2002. Effect of zinc source (zinc oxide vs zinc proteinate) and level on performance, carcass characteristics, and immune response of growing and finishing steers. Journal of Animal Science 80:2747-2752.

Subar, A.F., Krebs-Smith, S.M., Cook, A. and Kahle, L.L. 1998. Dietary sources of nutrients among US adults, 1989 to 1991. Journal of American Dietary Association 98:537-547.

Van Soest, P.J., Robertson, J.B. and Lewis, B.A. 1991. Methods of dietary fiber, neutral detergent fiber, nonstarch polysaccharides in relation to animal nutrition. Journal of Dairy Science 74:
3583-3597.

Wallach, J. 1974. Interpretation of Diagnostic Tests (2nd Ed.). Little, Brown and Company, Boston, MA.

Walz, L.S., White, T.W., Fernandez, J.M., Gemtry, L.R., Blouin, D.C., Froetschel, M.A., Brown, T.F., Lupton, C.J. and Chapa, A.M. 1998. Effect of fish meal and sodium bentonite on daily gain, wool growth, carcass characteristics, and ruminal and blood characteristics of lambs fed concentrate diets. Journal of Animal Science 76:2025-2031.

Westing, T.W., Fontenot, J.P., McClure, W.H., Kelly, R.F. and Webb, K.E. Jr. 1985. Characterization of mineral element profiles in animal waste and tissues from cattle fed animal waste. I. Heifers fed broiler litter. Journal of Animal Science 61:670-681.

Williams J.E., Wagner, D.G., Walters, L.E., Horn, G.W., Waller, G.R., Sims, P.L. and Guenther, J.J. 1983. Effect of production systems on performance, body composition and lipid and mineral profiles of soft tissue in cattle. Journal of Animal Science 57:1020-1028.

Yoon, I.K. and Stern, M.D. 1995. Influence of direct-fed microbes on ruminal microbial fermentation and performance of ruminants: a review. Asian-Australasian Journal of Animal Science 8: 533-555.

(Received November 16, 2012/Accepted November 26, 2012) 